Journal of English Language Teaching and Applied Linguistics

ISSN: 2707-756X

DOI: 10.32996/jeltal

Journal Homepage: www.al-kindipublisher.com/index.php/jeltal

JELTAL

\title{
Towards Achieving Sustainable Development in Nigeria: The Girl-Child Education Factor
}

\author{
Mary Chizoma Okere Ph.D \\ Directorate of General Studies, Federal University of Technology, Owerri, Imo State, Nigeria
}

$\square$ Corresponding Author: Mary Chizoma Okere Ph.D, E-mail: mcokere499@gmail.com

\section{ARTICLE INFORMATION}

Received: 01 September 2021

Accepted: 25 September 2021

Published: 24 October 2021

DOI: $10.32996 /$ jeltal.2021.3.11.4

\section{KEYWORDS}

Sustainable Development, Girlchild, Literacy/Education, Nigeria

\section{ABSTRACT}

It is the dream and aspiration of every nation to achieve development. Hence, the policies and laws of any nation, whether developed or developing, are geared towards achieving development in every sector. To promote socio-economic development globally, the United Nations Sustainable Development Goals (SDGs) were signed. The SDGs are the seventeen goals set and signed by the 193 UN member nations in 2015 and agreed to be achieved by 2030 . They represent a shared commitment by all member countries of which Nigeria is one to promote and ensure inclusive and equitable quality education and life-long learning opportunities for all, good health and well-being for all, gender equality, and empowerment of women and girls, among other time-bound goals through partnership. Before the SDGs, there were the eight Millennium Development Goals which were signed in 2000 by 189 heads of state to eradicate inter alia hunger and poverty, diseases, gender inequalities, etc. Four years after the 2015 target of the MDGs and four years into the SDGs 2030 target, there is still gender disparity in access to quality education between the boy-child and the girlchild in favor of the former in many countries including Nigeria. This is the reason this study sought to examine people's perception of girl-child education. The survey research design was adopted for the study. To provide answers to the research questions, a research instrument tagged "views on girl-child education questionnaire" was used to collect data. 144 people responded to the questionnaire. Results showed a generally negative perception of girl-child education among men and women. It was also discovered through the study that negative cultural beliefs about girl-child education, male child preference, and poverty are critical factors militating against gender parity in access to education. In the light of the findings of this study, it was recommended among others that government should pursue intensely its poverty alleviation programmes so that low socio-economic families could to an extent send all their children to school. It was also recommended to women organizations to increase the level of publicity given to issues concerning women.

\section{Introduction}

Issues concerning the girl-child in relation to the plight of women in patriarchal societies have over the years gained the attention of researchers. A girl-child in many countries of the world, including Nigeria does not have equal opportunities with the male child in virtually every aspect of life. Girl-child in this paper refers to a female biological offspring from birth to eighteen (18) years of age. It is the age before one becomes a young adult. This period covers the crèche, nursery or early childhood (0 - 5 years), primary (6 - 12 years), and secondary school (12-18years). During this period, the young child is totally under the care of the adult who may be her parents or guardians and older siblings. It is made up of infancy, childhood, early and late adolescence stages of development. During this period, the girl-child is malleable, builds and develops her personality and character. She is dependent on significant others on whom she models her behavior, through observation, repetition, and imitation. Her physical, mental, social, spiritual, and emotional developments start and progress to get to the peak at the young adult stage (Offorma,

Copyright: (c) 2021 the Author(s). This article is an open access article distributed under the terms and conditions of the Creative Commons Attribution (CC-BY) 4.0 license (https://creativecommons.org/licenses/by/4.0/). Published by Al-Kindi Centre for Research and Development, London, United Kingdom. 
2009). However, we wish to clarify that 'girl-child' as used here is representative. It represents the female gender. Hence, it would be used interchangeably with 'women' and 'female child'.

Whether a nation is developed or developing, the primary goal and objective of its policies are to achieve sustainable development in every sector. Sustainable development which according to the Bruntland Commission Report of 1987 is the development that meets the needs of the present without compromising the ability of future generations to meet their own needs suggests that sustainable development requires meeting the basic needs of all and extending to all the opportunities to satisfy their aspirations for a better life.

There is perhaps a no greater opportunity for one to satisfy one's aspirations for a better life than the opportunity of receiving quality education and training. Education, the world over, is considered as a strong weapon of social change, a bedrock of national socio-economic development, and an instrument for changing (for the better) the culture of oppression, ignorance, victimization, and perpetual dependence. Therefore, it is not only a means of liberation but also a necessity for the individual's growth and national development (Braimoh, 1998). This reinforces Almendarez's view (2010) that education creates improved citizens and helps to upgrade the general standard of living in a society. Hence, the twenty-first-century paradigm is shifting towards the enhancement of knowledge as a priority. However, in societies where gender discrimination is rife, access to education and training is lopsided in that there is a difference between the enrolment of males and females in all levels of education in favor of the males. A 2007 United Nations International Children Education Fund (UNICEF) report presents the global figure for out-of-school children at about 121 million out of which 65 million (about 53\%) are girls. The report further shows that over $80 \%$ of these girls live in sub-Saharan Africa which includes Nigeria.

It is stating the obvious that cannot be over-stressed that there is an overwhelming and gross oversight of the importance of girlchild education in national development in Nigeria as in some other countries. Development planning has failed to recognize fully or systematically the benefits of girl-child education or in turn the negative effects of her illiteracy on society. Hence, girls' education has always lagged behind that of boys and no state of the federation has ever attained a 50:50 enrolment of males and females. The present ratio of male-female enrolment in primary school is 6:4 (Adepoju, 2008). The statistics of primary school enrolment for five consecutive years lend credence to Adepoju's assertion.

Table 1: Primary School (public and private) Enrolment by Class and Gender for 2011/2012 - 2015/2016 Academic Years

\begin{tabular}{|c|c|c|c|c|c|c|c|c|c|c|}
\hline \multirow[t]{2}{*}{ Class } & \multicolumn{10}{|c|}{ Academic Year } \\
\hline & \multicolumn{2}{|c|}{ 2011/2012 } & \multicolumn{2}{|c|}{$2012 / 2013$} & \multicolumn{2}{|c|}{$2013 / 2014$} & \multicolumn{2}{|c|}{$2014 / 2015$} & \multicolumn{2}{|c|}{$2015 / 2016$} \\
\hline \multirow[t]{2}{*}{ Pry 1} & $M$ & $\mathrm{~F}$ & $M$ & $\mathrm{~F}$ & $M$ & $\mathrm{~F}$ & $M$ & $\mathrm{~F}$ & $M$ & $\mathrm{~F}$ \\
\hline & 2581145 & 2280982 & 2636528 & 2469691 & 2536051 & 2265460 & 2547233 & 2285300 & 2743132 & 2460501 \\
\hline \multirow[t]{2}{*}{ Pry 2} & $\mathrm{M}$ & $\mathrm{F}$ & $\mathrm{M}$ & $\mathrm{F}$ & $\mathrm{M}$ & $\mathrm{F}$ & $\mathrm{M}$ & $\mathrm{F}$ & $\mathrm{M}$ & $\mathrm{F}$ \\
\hline & 2383171 & 2128497 & 2467992 & 2302244 & 2410079 & 2158808 & 2411200 & 2176654 & 2434509 & 2204981 \\
\hline \multirow[t]{2}{*}{ Pry 3} & $\mathrm{M}$ & $\mathrm{F}$ & M & $\mathrm{F}$ & M & $\mathrm{F}$ & $\mathrm{M}$ & $\mathrm{F}$ & $\mathrm{M}$ & $\mathrm{F}$ \\
\hline & 2288321 & 2032459 & 2327900 & 2203294 & 2301354 & 2656416 & 2353436 & 2112051 & 2338894 & 2135704 \\
\hline \multirow[t]{2}{*}{ Pry 4} & $\mathrm{M}$ & $\mathrm{F}$ & $\mathrm{M}$ & $\mathrm{F}$ & M & $\mathrm{F}$ & $\mathrm{M}$ & $\mathrm{F}$ & M & $\mathrm{F}$ \\
\hline & 2130882 & 1895760 & 2191630 & 2050442 & 2163234 & 1963847 & 2218251 & 2005261 & 2177456 & 1990384 \\
\hline \multirow[t]{2}{*}{ Pry 5} & $\mathrm{M}$ & $\mathrm{F}$ & $\mathrm{M}$ & $\mathrm{F}$ & $M$ & $\mathrm{~F}$ & $\mathrm{M}$ & $\mathrm{F}$ & $\mathrm{M}$ & $\mathrm{F}$ \\
\hline & 1975173 & 1752853 & 2017076 & 1895219 & 1988428 & 1784579 & 2016039 & 1822964 & 2003384 & 1813718 \\
\hline \multirow[t]{2}{*}{ Pry 6} & $\mathrm{M}$ & $\mathrm{F}$ & $\mathrm{M}$ & $\mathrm{F}$ & M & $\mathrm{F}$ & $\mathrm{M}$ & $\mathrm{F}$ & M & $\mathrm{F}$ \\
\hline & 1808375 & 1635824 & 1853640 & 1742719 & 1856643 & 1716298 & 1847151 & 1646995 & 1738565 & 1549953 \\
\hline \multirow[t]{2}{*}{ Total } & $\mathrm{M}$ & $\mathrm{F}$ & $M$ & $\mathrm{~F}$ & $\mathrm{M}$ & $\mathrm{F}$ & $\mathrm{M}$ & $\mathrm{F}$ & $M$ & $\mathrm{~F}$ \\
\hline & $\begin{array}{l}1316706 \\
7\end{array}$ & $\begin{array}{l}117263 \\
75\end{array}$ & $\begin{array}{l}134947 \\
66\end{array}$ & $\begin{array}{l}1266360 \\
9\end{array}$ & $\begin{array}{l}132557 \\
89\end{array}$ & $\begin{array}{l}125454 \\
08\end{array}$ & $\begin{array}{l}1339331 \\
0\end{array}$ & $\begin{array}{l}1204922 \\
5\end{array}$ & $\begin{array}{l}134359 \\
40\end{array}$ & 12155241 \\
\hline
\end{tabular}

Source: Federal Ministry of Education (Online). http://education.gov.ng/nigeria-digest-of-education-statistics/

Table 1 reveals that for five years boys' enrolment into primary schools has consistently been higher than that of girls. The slight improvement in girls' enrolment recorded in the 2013/2014 academic year in primary three was not sustained. This trend negates the nation's philosophy of education which is based among other objectives: the provision of equal access to educational opportunities for the citizens of the country at the primary, secondary and tertiary levels of both inside and outside the formal school system (NPE, 2004). To make matters worse, while many sub-African countries are trying to reduce the number of out-ofschool children through budgetary allocation to education, such cannot be said about Nigeria. Business Day Newspaper of February 4, 2019, in its editorial, observes that in today's world when every nation has shifted attention to education and investing 
heavily in it as the bedrock for development, Nigeria continues to pay lip services to the education of her citizens. This is evident in the degrading $7 \%$ of her 2018 budget allocated to education. In a situation like this, the girl-child bears the brunt.

Nigeria is a patriarchal society where preference is given to the male child in virtually every aspect of life. The right to education is for everyone- male and female yet education is denied to a large number of females. This is not because it is the policy of the government, but because of ignorance. For instance, when parents could not afford to educate all their children, the male child or children are given preference for 'valid' reasons like 'a male child will eventually be a breadwinner of a family' and 'girls are better hawkers and are of immediate help to their petty trading mothers'. The resultant effect is a wide gender gap in access to education and training at the expense of the girl-child. This is inimical to national development. The development would be achieved and sustained when every member of a nation is empowered to participate in the development processes. As Oke (2001) puts it, "a person does not walk very far or very fast on one leg. How can we expect half the people to be able to develop the nation?" All hands must be on deck to achieve sustainable national development. Education no doubt is a veritable tool for empowering an individual for self-development and maximum use of his potentials. It is against this background that this study seeks to examine public perception of girl-child education and the social, economic, political, cultural, and religious factors that pose the greatest challenge to gender parity in access to education and training.

\section{Theoretical Framework}

Discussions and arguments in this paper are guided by the liberal feminism paradigm. The liberal feminism paradigm is premised on the notion that women as a group are disadvantaged. It proposes that women are rational beings like men because there is no evidence as to the proof of the superiority of the $\mathrm{Y}$ chromosome of the male sex over the $\mathrm{X}$ chromosome. To this end, women are entitled to the same legal and political rights as men. The paradigm campaigns for women's right to education, employment, political participation, and full legal equality.

One of the leading proponents of the liberal feminism paradigm is Mary Wollstonecraft (1759-1797). In the work a Vindication of Rights of Woman: with Strictures on Political and Moral Subjects (1792), Wollstonecraft argued that education is the means to end women's marginalization. In the introduction to the book, the author decried the exclusion of women from formal education. She said: "I have turned over various books written on the subject of education and patiently observed the conduct of parents and the management of schools; but what has been the result? A profound conviction that the neglected education of my fellow-creatures is the grand source of the misery I deplore." Thus, she advocated universal and freely accessible education because if women were afforded the same opportunities and education, they could contribute as much to society as men.

The liberal feminism paradigm is relevant to this study because it recognizes the importance of education in bridging the economic and political gaps between the male and female genders. It also emphasizes education as an empowerment tool for women's contribution to national development.

\section{Girl-child Education and Sustainable National Development}

The importance of women's education in national development cannot be over-stressed. According to Dozie and Njemanze (2013), integration of women in development through education changes the graph of national development in the global era from good to better and even best. It is a well-known saying that when you train a man, you train an individual but when you train or educate a woman, a family and by extension, a nation is trained or educated. Although male chauvinists have misconstrued the real meaning of the saying, the message embedded in it is obvious. For male chauvinists, the saying is an acknowledgment and a confirmation that a woman's education ends in the kitchen. That is, after receiving training (education) outside the home, she goes back there and remains there.

Despite the distortion of the import of this maxim, one could say that women's greatest contribution to national development is discharged in their role as mothers. Just as Agu (2008) opines, sustainable national development starts from human capital development and this begins with the family. So, if each family could imbue and sustain in its members the virtues of high morals, then the nation's development will be accelerated. Women are by nature nation builders. They are great educators. It is said that a mother is the first teacher of a child and so she remains. A woman who has received the right education will inculcate moral values into her children. This leads to national development. For instance, children who have been raised to appreciate the dignity of labor would hardly fall into the trap of get-rich-quick syndrome which is prevalent among youths of today. This problem could account for over $90 \%$ of the social vices among the youths and it is inimical to development in all its ramifications.

The role of girl-child education in sustainable national development is invaluable. Girl-child education reduces her fertility rates. An educated girl rather than being married off early will have her marriage and childbearing delayed. When she is eventually married, she is much more likely to use reliable family planning methods and have fewer and healthier babies than women with no formal education (Omede \& Agahiu, 2016). This development enhances national development. 


\subsection{Research Questions}

These two research questions were raised and answered.

1. How do respondents perceive girl-child education?

2. What factors pose the greatest challenge to gender parity in access to education and training in Nigeria?

\section{Methodology}

\subsection{Research Design}

The study adopted the survey research design.

\subsection{Research Instrument}

The researcher collected data through a questionnaire tagged "Views on Girl-child Education Questionnaire (VOGCEQ) developed by the researcher to examine respondents' perception of girl-child education and the greatest hindrances to gender parity in access to education. 150 copies of the questionnaire were distributed to the target population purposively selected out of which 144 copies were returned. The instrument has two sections. Section A contains two questions on demographic information of the respondents and section $B$ also contains two questions that require respondents to pick options. To determine the face and content validity of the instrument, the first draft was given to two Measurement and Evaluation lecturers of the Institute of Education of the University of Ibadan for their expert assessment and suggestions. Their advice was incorporated into the final draft. The trialtest results of the final draft administered on 30 respondents from a location different from the location of the actual participants showed no ambiguities in the questionnaire items.

\subsection{Data Collection Procedure and Analysis}

The questionnaires were self-administered. Respondents were visited at home, place of work, and along the streets. Descriptive statistics involving frequency counts and percentage scores were used to analyze data generated from the questionnaires.

\section{Results and Discussion}

Table 2: Distribution of Respondents by Age and Sex

\begin{tabular}{|l|l|l|l|l|l|l|}
\hline \multirow{2}{*}{ Age range } & \multicolumn{3}{|c|}{ Sex } & \multicolumn{2}{c|}{$\begin{array}{c}\text { Total } \\
\text { No. of } \\
\text { Respondents }\end{array}$} \\
\cline { 2 - 7 } & \multicolumn{3}{|c|}{ Male } & \multicolumn{2}{c|}{ Female } & \multicolumn{2}{c}{} \\
\cline { 2 - 7 } & No. & $\%$ & No. & $\%$ & No. & $\%$ \\
\hline $18-25$ & 6 & 4.17 & 2 & 1.39 & 8 & 5.56 \\
\hline $26-33$ & 2 & 1.39 & 5 & 3.47 & 7 & 4.86 \\
\hline $34-41$ & 18 & 12.5 & 32 & 22.22 & 50 & 34.72 \\
\hline $42-49$ & 29 & 20.14 & 20 & 13.89 & 49 & 34.03 \\
\hline 50 and above & 8 & 5.55 & 22 & 15.28 & 30 & 20.83 \\
\hline Total & 63 & 43.75 & 81 & 56.25 & 144 & 100 \\
\hline
\end{tabular}

Table 2 shows that there were more female than male respondents. Out of the 144 respondents sampled, 63(43.75\%) were males while $81(56.25 \%)$ were females. This could be as a result of the sampling technique which was purposive since respondents were chosen based on availability. Almost all the females approached to take part in the study obliged whereas most males approached declined.

The study also tried to find out the age bracket of the respondents. As shown in table 2 while all the respondents were adults, the majority of the 50(34.72) fall within the age bracket of 34-41 years. $49(34.03 \%)$ respondents were within the age bracket of $42-49$ years while $30(20.83 \%)$ and $15(10.42 \%)$ fall within the age brackets of $50^{+}$and $18-33$ respectively. It could therefore be said that the respondents were adults who are likely to have a full grasp of the issue under study. Hence, it could be assumed that whatever responses that would come from them are a true reflection of their views. 
Research Question 1

How do respondents perceive girl-child education?

Table 3: Respondents' Perception of Female Education

\begin{tabular}{|c|c|c|c|c|}
\hline Statements & Yes & $\%$ & No & $\%$ \\
\hline 1. A female child should receive as much education as a boy. & 51 & 35.42 & 93 & 64.58 \\
\hline 2. A girl-child does not need the education to fulfill her roles in society. & 95 & 65.97 & 49 & 34.03 \\
\hline 3. The highest level of education a female child should receive is O'Level. & 70 & 48.61 & 74 & 51.39 \\
\hline 4. Female child education is an invaluable investment. & 102 & 70.83 & 42 & 29.17 \\
\hline 5. A female child's education benefits a family more than a male child's. & 58 & 40.28 & 86 & 59.72 \\
\hline $\begin{array}{l}\text { 6. When a family cannot afford to send all the children to school, } \\
\text { preference should be given to male children. }\end{array}$ & 68 & 47.22 & 76 & 52.78 \\
\hline $\begin{array}{l}\text { 7. Education equips women for optimal contribution to sustainable } \\
\text { national development. }\end{array}$ & 98 & 68.06 & 46 & 31.94 \\
\hline 8. Educated women are disobedient and arrogant. & 83 & 57.64 & 61 & 42.36 \\
\hline 9. Education will interfere with a woman's matrimonial responsibilities. & 119 & 82.64 & 25 & 17.36 \\
\hline
\end{tabular}

Table 2 shows that a good number of the respondents 102(70.83\%) perceive girl-child education as an invaluable investment, education equips women for optimal contribution to sustainable national development 98(68.06) and that male children should not be given preference when a family could not afford to send all the children to school 76(52.78\%). On the negative side, the majority of the respondents $119(82.64 \%)$ are of the view that education will interfere with a woman's matrimonial roles. 95(65.97\%) affirm that a girl-child does not need the education to fulfill her roles in society while 93(64.58\%) are of the view that a girl-child should not receive as much education as the boy-child. Another negative perception of girl-child education worth mentioning here is that educated women are disobedient and arrogant as indicated by $83(57.64 \%)$ of the respondents.

Meanwhile, despite the fact that over $70 \%$ of the respondents acknowledge that girl-child education is an invaluable investment, over $80 \%$ agree that education will interfere with a woman's matrimonial roles or responsibilities. Whichever way the negative perception held by respondents about girl-child education is interpreted, it seems that the prevailing values, norms, beliefs, and cultural practices perform the ideological function of maintaining gender disparity in access to education in Nigeria. However, since the majority of the respondents are women (see table 2) one could infer from this result that women themselves see their matrimonial functions as a top priority. The finding supports Omede and Agahiu's (2016) submission that in most African societies, especially in Nigeria, the role of the girl as a wife and mother is conceived as the utmost priority not only by her parents but also by the girl-child herself.

This is worrisome because it presupposes that women's matrimonial roles have been so elevated that a woman who cannot perform them for whatever reason is seen as defiling femininity. Hence, in traditional African societies, women are so engrossed in meeting societal expectations that they lag behind in the other spheres of life (Anah \& Okere, 2019). This has kept women in their 'permanent' and 'sacred' place of work- the home. The answer to research question 1 therefore, is that men and women have a negative perception of girl-child education. This result is similar to that of Mollel and Chong (2017) which revealed that parents and the community, in general, have a negative perception of girls' education. This has a far-reaching effect on efforts at bridging the gap between male and female access to education in sub-Saharan Africa. 
Research Question 2

What factors pose the greatest challenge to gender parity in access to education in Nigeria?

Table 4: The order in which respondents think the factors pose a problem to gender parity in access to literacy/education

\begin{tabular}{|c|c|c|c|c|c|c|c|c|c|c|c|c|c|}
\hline \multicolumn{2}{|r|}{ Factors } & $1^{\text {st }}$ & $2^{\text {nd }}$ & $3^{\text {rd }}$ & $4^{\text {th }}$ & $5^{\text {th }}$ & $6^{\text {th }}$ & $7^{\text {th }}$ & $8^{\text {th }}$ & $9^{\text {th }}$ & $10^{\text {th }}$ & Total & Rank \\
\hline 1 & Poverty/Financial difficulties & 20 & 17 & 20 & 29 & 8 & 12 & 10 & 23 & 3 & 2 & 941 & $3^{\text {rd }}$ \\
\hline 2 & Early marriage & 4 & 1 & 18 & 27 & 20 & 17 & 5 & 22 & 5 & 25 & 708 & $7^{\text {th }}$ \\
\hline 3 & $\begin{array}{l}\text { Inadequate policies/laws to remove barriers to girl- } \\
\text { child's access to education }\end{array}$ & - & 10 & - & 8 & 26 & 21 & 16 & 19 & 30 & 14 & 602 & $10^{\text {th }}$ \\
\hline 4 & Male child preference & 38 & 26 & 15 & 17 & 4 & 7 & 13 & 13 & 11 & - & 1025 & $2^{\text {nd }}$ \\
\hline 5 & Parents'/Mother's illiteracy & 24 & 30 & 18 & - & 21 & 12 & 6 & 4 & 11 & 18 & 916 & $5^{\text {th }}$ \\
\hline 6 & Teenage pregnancy & 15 & 3 & 6 & 12 & 23 & 18 & 21 & 14 & 4 & 28 & 699 & $9^{\text {th }}$ \\
\hline 7 & Negative cultural beliefs about girl-child education & 33 & 14 & 37 & 16 & 9 & 6 & 12 & 3 & 12 & 2 & 1031 & $1^{\text {st }}$ \\
\hline 8 & Insecurity/Violence & 20 & 4 & 12 & 7 & 3 & 15 & 17 & 40 & 13 & 13 & 701 & $8^{\text {th }}$ \\
\hline 9 & Domestic duties & 34 & 22 & 16 & 10 & 18 & 4 & 1 & 10 & 9 & 20 & 936 & $4^{\text {th }}$ \\
\hline 10 & Girl-child's lack of interest in education & 7 & 2 & 21 & 9 & 26 & 23 & 19 & 14 & 18 & 5 & 749 & $6^{\text {th }}$ \\
\hline
\end{tabular}

Note: Starting from $7^{\text {st }}-10^{\text {th }}, 7^{\text {st }}$ has a value of $10,2^{\text {nd }}=9,3^{\text {rd }}=8,4^{\text {th }}=7,5^{\text {th }}=6,6^{\text {th }}=5,7^{\text {th }}=4,8^{\text {th }}=3,9^{\text {th }}=2$ and $10^{\text {th }}=1$ Findings, as presented in Table 4, show that negative cultural beliefs about girl-child education rank first with a total value of 1,031 followed by male child preference with 1,025 values. The third factor in the ranking is poverty/financial difficulties 941 . Coming next is domestic duties. Table 4 also shows that respondents think that inadequate policies/laws to remove barriers to girl-child's access to education is not a major hindrance to gender parity in access to education as it ranked last. This result more or less confirmed what was obtained in Table 3 were the responses from the respondents showed a negative perception of girl-child education.

The finding that negative cultural beliefs about girl-child education are a critical factor militating against equal access to education between the male child and the female child tends to support Hari's (n.d) view that traditional beliefs have been found to foster negative attitudes which limit family and community support for girls' education. Ironically, the most popular negative cultural belief which tends to perpetuate gender disparity in access to education is parents' view that investing in a female child's education is not worthwhile because she will marry into another family. Thus, the returns on her education will be for her husband and his people.

The result also revealed that male child preference is another key obstacle to girl-child's equal access to education with the boychild. This could be expected. Male child preference for every good thing in life is an age-old tradition in many cultures, especially in Africa. The phenomenon is recorded in many traditional and modern African literary narratives. In traditional African societies, a male child is valued more than a female child for a somewhat valid reason that it is a male child that bears the family's name. He is the one that continues the father's lineage. Thus, the anguish of a 'sonless' family knows no bounds. This has given rise to names like "Ahamefula", "Eziefula" or "Amaefula" which literally means "my name or lineage has been redeemed from extinction". With this high premium placed on the male child, it is to be expected that he will be given preference for education.

Another factor that received high ranking in the study as an obstacle to male and female equal access to education is poverty/ financial difficulties. This has often been cited as a major hindrance to girl-child's access to education. The rationale behind this view is the fact that there is large-scale poverty in Africa, especially among women. Citing Conte (2000), Udoh (2001) notes that figures provided by the United Nations speak of a pitiless plight: $70 \%$ of the poor and two-thirds of the illiterate in the world are females. Thus, due to poverty and ignorance the girl-child more often than not, drops out of school or never gets enrolled in order to assist her petty-trading mother to raise money for her brother's education. We, therefore, answer research question 2 by saying that negative cultural beliefs about girl-child education, male child preference, and poverty/financial difficulties are critical factors militating against gender parity in access to education.

\section{Conclusion}

This study has attempted to examine how men and women perceive girl-child education and to identify the factors that pose the greatest obstacle to gender equality in access to education. Following the analysis of data and discussion of findings, the study, 
therefore, arrives at the conclusion that there is a negative perception of women's education among men and women and this is a major factor militating against male and female equal access to education.

\section{Recommendations}

Based on the findings of this study the following recommendations are made:

1. There is a need for a positive change of perception about the value of girl-child education. The traditional assumption that a woman's education ends in the kitchen should be dropped.

2. Cultural practices and norms that encourage male child preference in virtually all spheres of life should be abolished. The girl-child is as important as the male child.

3. Poverty alleviation programs of the government should be pursued intensely so that low socio-economic families can to an extent send all their children to school.

4. Laws that punish parents for not sending their female children to school should be promulgated.

5. Government at various levels should put into action their free education policies rather than paying lip services to such.

6. Women organizations should increase the level of publicity given to women's issues.

Funding: This research received no external funding.

Conflict of Interest: The author declares no conflict of interest.

\section{References}

[1] Agu, P. C. (2008). The Family and Nation Building. Port Harcourt: Prelyn Publishers

[2] Adepoju, A. (2008). Perceived Hindrances to Females Access to Literacy and/or Education in selected States from Southwestern Nigeria. African Journal of Educational Research, 12(2), 196-200.

[3] Almendarez, L. (2010). Human Capital Theory: Implications for Educational Development. (Online)Available:https://www.open.uwi.edu/sites/default/files/bnccde/belize/conference/papers2010/almendarez.html (August 20, 2019)

[4] Anah, C. I. \& Okere, M. C. (2019). The Social Construction of Gender in Traditional Igbo Societies: A Comparative Study of Language Used as Socialisation in John Munonye's The Only Son and Flora Nwapa's Efuru. Research on Humanities and Social Sciences, Vol.9, No.10; 84-90.

[5] Bruntland Commission Report, 1987. (Online) Available: www.krynica-zdroj.pl/files/files/Files/Srodowisko/Bruntland_Report_Extracts.pdf (August 25, 2019)

[6] Braimoh, D. (1998). Distance Education Programme: A Precursor to National Manpower Development in Lesotho. Indian Journal of Open Learning, 7(2), 155-169.

[7] Dozie, C. P. \& Njemanze, Q. U. (2013). The Role of Women Education in National Development. International Journal of Gender and Development Issues, 1(1), $144-149$.

[8] Federal Republic of Nigeria (FRN,2004). National Policy on Education. National Education Research and Development Council, Abuja, Nigeria.

[9] Hari, P. (n. d). Parents and Community Attitudes towards Girls' Participation in and Access to Education, Science, Mathematics and Technology (SMT) Subjects. (Online) Available:www.unesco.org/education/educprog/ste/projects/girls\%20africa/femsa/femsa6.html (September 9, 2019)

[10] Mollel, N. S. \& Chong, R. (2017). Socio-Cultural Constraints of Girls' Access to Education in Mtwara District, Tanzania. Khazar Journal of Humanities and Social Sciences, 20 (3), 108-125. (Online) Available: http://jhss-khazar.org/wp-content/uploads/2017/09/2017.7.NEEMAPAPER-edited 2 1.pdf (September 9, 2019)

[11] Offorma, G.C. (2009). Girl-Child Education in Africa. (Online) Available: https://www.researchgate.net/publication/280554452 GIRLCHILD_EDUCATION_IN_AFRICA (August 28, 2019)

[12] Oke, R. O. (2001). Inheritance in Africa and the Rights of the Female-Child. In D. O. Akintunde (ed). African Culture and the Quest for Women's Rights. Ibadan: Sefer Books Ltd. 50-57.

[13] Omede, A. A. \& Agahiu, G. E. (2016). The Implications of Girl-Child Education to Nation Building in the $21^{\text {st }}$ Century in Nigeria. Global Journal of Human-Social Science: $G$ Linguistics and Education, 16(3), $1-4$.

[14] Udoh, C. O. (2000). The tragedy of the Girl-Child. Ibadan Journal of Educational Studies, 1(1), 1-10. 